\title{
Left Ventricular Pseudoaneurysm Following Inferior Myocardial Infarction: A Case for Conservative Management
}

\author{
Jonathan Ludmir ${ }^{\mathrm{a}, \mathrm{b}}$, Karan Kapoor ${ }^{\mathrm{a}}$, Praveen George ${ }^{\mathrm{a}}$, Jasjeet Khural ${ }^{\mathrm{a}}$, \\ Brian Barr ${ }^{\mathrm{a}}$
}

\begin{abstract}
Left ventricular pseudoaneurysm is a rare complication of myocardial infarction that carries a high mortality rate. Although conventional wisdom suggests prompt surgical repair in order to mitigate risk of expansion and rupture, there are some data to support non-operative management in asymptomatic individuals with likely chronic pseudoaneurysms, particularly when surgical candidacy is poor. We present a case of a medically managed left ventricular pseudoaneurysm subsequent to inferior ST-segment elevation myocardial infarction with 6-month follow-up data.
\end{abstract}

Keywords: Pseudoaneurysm; Left ventricular mass; Echocardiography

\section{Introduction}

Left ventricular pseudoaneurysm is a rare complication of myocardial infarction (MI) associated with serious morbidity and mortality [1]. Unlike true ventricular aneurysms in which the integrity of the myocardial wall is maintained, pseudoaneurysm forms when cardiac rupture is contained by adherent fibrous tissue and pericardium. Although challenging to diagnose, advances in non-invasive imaging have enhanced identification of this condition and increased detection of incidental pseudoaneurysms in otherwise asymptomatic individuals [2]. The natural history of untreated left ventricular pseudoaneurysm is based predominantly on retrospective single-center case series and remains largely undefined. Left ventricular pseudoaneurysms render a $30-45 \%$ risk of rupture [1]. However, there are retrospective data that suggest a lower risk of rupture amongst a subset of chronic pseudoaneurysms [3]. Concomitantly, post-operative mortality after surgical repair

\footnotetext{
Manuscript accepted for publication January 11, 2016

${ }^{a}$ University of Maryland Medical Center, Baltimore, MD, USA

${ }^{b}$ Corresponding Author: Jonathan Ludmir, University of Maryland Medical Center, 22 South Greene Street, Baltimore, MD 21201, USA.

Email: Jludmir@medicine.umaryland.edu
}

doi: http://dx.doi.org/10.14740/cr449w of left ventricular pseudoaneurysm is high, ranging from $23 \%$ to $50 \%$ in some series $[2,4,5]$. We present a case of left ventricular pseudoaneurysm following inferior ST-elevation MI.

\section{Case Report}

A 68-year-old man with history of chronic obstructive pulmonary disease and asbestos-related pneumoconiosis presented with chest pain and diaphoresis after a motor vehicle accident. Electrocardiogram revealed ST elevations in the inferior leads. The patient was promptly taken to the cardiac catheterization lab where he was found to have complete occlusion of the distal right coronary artery. The patient underwent successful percutaneous coronary intervention of the right coronary artery with placement of a drug eluding stent. One day after the coronary intervention, he remained asymptomatic when echocardiogram revealed a left ventricular pseudoaneurysm in the distal inferolateral wall (Fig. 1). Left ventricular ejection fraction (LVEF) was $40 \%$, and no valvular abnormalities or pericardial effusion were detected. The patient subsequently underwent cardiac computed tomography which confirmed the diagnosis. A $1 \times 2 \mathrm{~cm}$ outpouching was visible along the inferolateral left ventricular wall at the mid cavity level, consist-

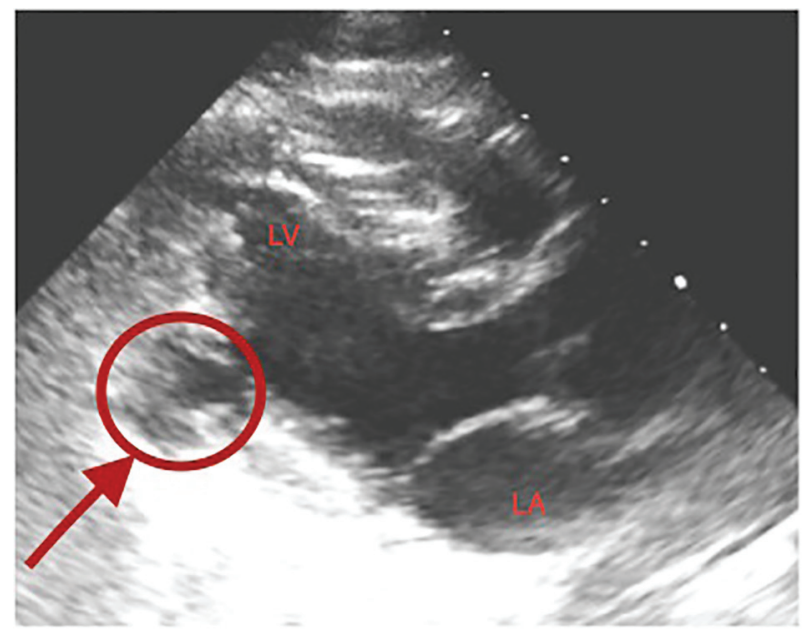

Figure 1. Transthoracic echocardiogram demonstrating left ventricular pseudoaneurysm (arrow) in the distal inferolateral wall. 

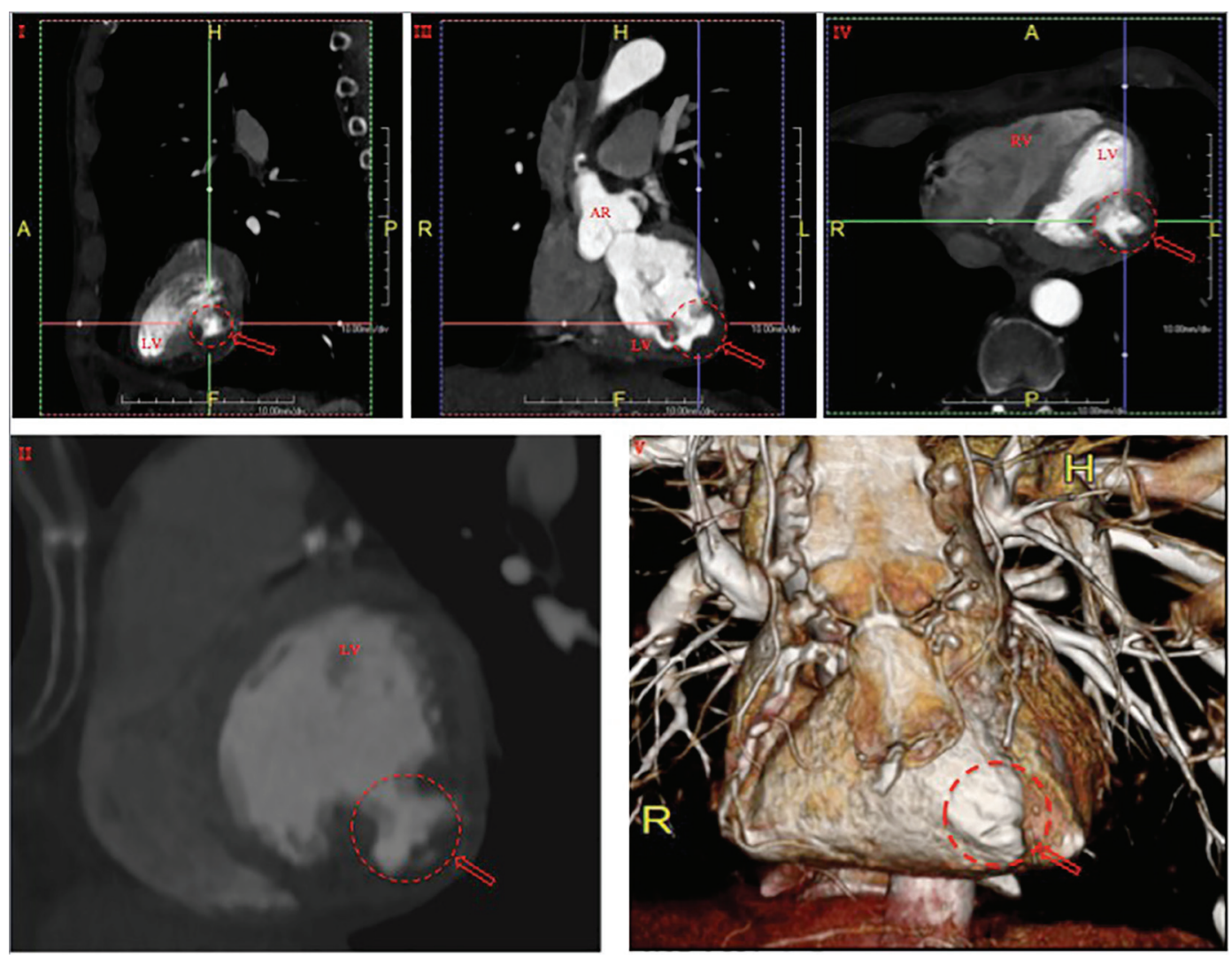

Figure 2. Cardiac computed tomography demonstrating a $1 \times 2 \mathrm{~cm}$ outpouching along the inferolateral left ventricular wall at the mid cavity level in sagittal (I, II), coronal (III), axial (IV) and three-dimensionally reconstructed (V) views, consistent with pseudoaneurysm (arrows). RV: right ventricle; LV: left ventricle; AR: aortic root.

ent with a pseudoaneurysm (Fig. 2, Supplementary video 1, www.cardiologyres.org). In light of his underlying pulmonary disease conferring a high surgical risk, the patient opted for medical therapy alone with an angiotensin converting enzyme inhibitor. At 6 months follow-up, the patient remains asymptomatic and his echocardiogram is unchanged.

\section{Discussion}

A rare complication of either transmural MI or cardiac surgery, acquired pseudoaneurysm of the left ventricle, poses a difficult management dilemma, particularly among hemodynamically stable patients who are asymptomatic yet poor surgical candidates. The risk of expansion and eventual rupture must be balanced against a high surgical mortality, but the rarity of the condition has made understanding its natural history and identifying the highest risk patients challenging.

Risk factors for development of left ventricular pseudoaneurysm include female sex, first occurrence of either lateral or anterior wall MI, age greater than 60 years and severe single-vessel coronary artery disease, the latter two of which were features in our patient [6]. The clinical presentation is also highly variable, ranging from asymptomatic (up to $50 \%$ in one series) to syncope, arrhythmia, heart failure or severe angina [3]. Transthoracic echocardiography is widely regarded as an appropriate initial diagnostic assessment, although this may be followed by cineventriculography or cardiovascular magnetic resonance imaging given the high false negative rate associated with the former [7,8]. Risk factors for eventual rupture have not been clearly delineated, although larger size, posterolateral location and poor collateral circulation have all been suggested as potential predictors [2]. Notably, time till development of pseudoaneurysm does not reliably predict risk of expansion, as both early (within $48 \mathrm{~h}$ ) and late (greater than $48 \mathrm{~h}$ ) post-infarction pseudoaneurysms have similar rates of rupture $[6,9,10]$.

Conservative management of left ventricular pseudoaneurysms has been described in several case series (Table $1[1$, $3-5,11])$. Natarajan and colleagues reviewed a total of 66 cases of post-infarction pseudoaneurysm published between 1984 and 1993, demonstrating that medical management of chronic pseudoaneurysm (diagnosed 3 or more months following MI) was not associated with an increased risk of rupture [12]. In the largest series to date, Frances et al reported a 48\% (15 of 31 patients) mortality within 1 week of pseudoaneurysm diagnosis [1]. However, the remaining 16 medically managed patients had median survival of 3 years. The authors speculated the high mortality rate to relate to the relatively large size of pseudoaneurysm in their series (median posteroanterior diameter of $6 \mathrm{~cm}$, median orifice diameter of $2 \mathrm{~cm}$ ). Furthermore, $40 \%$ of the conservatively managed cohort was lost to follow- 
Table 1. Select Case Series Reviewing the Natural History and Treatment Outcomes of Left Ventricular Pseudoaneurysms

\begin{tabular}{|c|c|c|c|c|c|c|c|c|}
\hline Authors & Study type & $\mathbf{n}$ & $\begin{array}{l}\text { Age, } \\
\text { years }\end{array}$ & $\begin{array}{l}\text { Type and } \\
\text { location, \% }\end{array}$ & $\begin{array}{l}\text { Causes of } \\
\text { pseudoaneurysm, \% }\end{array}$ & $\begin{array}{l}\text { Management } \\
\text { type, } \mathbf{n}\end{array}$ & $\begin{array}{l}\text { Follow-up } \\
\text { period }\end{array}$ & Mortality findings \\
\hline $\begin{array}{l}\text { Yeo et al, } \\
1998[3]\end{array}$ & $\begin{array}{l}\text { Retrospective } \\
\text { case series }\end{array}$ & 52 & $\begin{array}{l}\text { Mean } \\
48 \pm 28\end{array}$ & $\begin{array}{l}\text { Left ventricle } \\
\text { Inferior/ } \\
\text { posterolateral, } 35 \\
\text { Sub-MV, } 8 \\
\text { Subaortic, } 6 \\
\text { Right ventricle } \\
\text { RVOT, } 25\end{array}$ & $\begin{array}{l}\text { Surgery, } 58 \\
\text { MI, } 42\end{array}$ & $\begin{array}{l}\text { Surgical, } 42 \\
\text { Medical, } 10\end{array}$ & $\begin{array}{l}\text { Median of } \\
2.3 \text { years }\end{array}$ & $\begin{array}{l}\text { Surgical mortality } \\
31 \% \text { at } 2.3 \text { years } \\
\text { Medical } 60 \% \text { at } 2.3 \\
\text { years (no deaths } \\
\text { due to rupture) }\end{array}$ \\
\hline $\begin{array}{l}\text { Frances } \\
\text { et al, } \\
1998[1]\end{array}$ & $\begin{array}{l}\text { Systematic } \\
\text { review }\end{array}$ & 244 & $\begin{array}{l}\text { Median } \\
60\end{array}$ & $\begin{array}{l}\text { Left ventricle } \\
\text { Posterior, } 43 \\
\text { Lateral, } 28 \\
\text { Apical, } 24 \\
\text { Inferior, 19 } \\
\text { Anterior, } 18 \\
\text { Basal, 14 }\end{array}$ & $\begin{array}{l}\text { MI, } 55 \\
\text { Surgery, } 33 \\
\text { Trauma, } 7 \\
\text { Infection, } 5\end{array}$ & $\begin{array}{l}\text { Surgical, } 193 \\
\text { Medical, } 51\end{array}$ & $1-10$ years & $\begin{array}{l}\text { Surgical post- } \\
\text { operative mortality } \\
<3 \text { days } 23 \% \text {, } \\
\text { remainder alive } \\
\text { till about } 4 \text { years; } \\
\text { Medical mortality } \\
\text { at }<1 \text { week, } 48 \% \text {, } \\
61 \% \text { at } 1 \text { year, } \\
84 \% \text { at } 5 \text { years, } \\
94 \% \text { at } 10 \text { years }\end{array}$ \\
\hline $\begin{array}{l}\text { Pretre et } \\
\text { al, } 2000 \\
{[5]}\end{array}$ & $\begin{array}{l}\text { Retrospective } \\
\text { case series }\end{array}$ & 10 & Mean 66 & $\begin{array}{l}\text { Left ventricle } \\
\text { Inferior, } 80 \\
\text { Lateral, } 10 \\
\text { Anterior, } 10\end{array}$ & $\begin{array}{l}\text { MI, } 70 \\
\text { Surgical, } 30\end{array}$ & Surgical, 10 & $\begin{array}{l}\text { Median } 45 \\
\text { months }\end{array}$ & $\begin{array}{l}\text { Surgical mortality } \\
28 \% \text { in post-MI } \\
\text { group; overall } 30 \%\end{array}$ \\
\hline $\begin{array}{l}\text { Moreno } \\
\text { et al, } \\
2003[11]\end{array}$ & $\begin{array}{l}\text { Retrospective } \\
\text { case series }\end{array}$ & 10 & $\begin{array}{l}\text { Mean } \\
63 \pm 12\end{array}$ & $\begin{array}{l}\text { Left ventricle } \\
\text { Inferior, } 6 \\
\text { Anterior, } 3 \\
\text { Anterior/ } \\
\text { inferior, } 1\end{array}$ & MI, 10 & $\begin{array}{l}\text { Surgical, } 1 \\
\text { Medical, } 9\end{array}$ & $\begin{array}{l}\text { Mean } 3.8 \\
\text { years }\end{array}$ & $\begin{array}{l}\text { Medical mortality } \\
\text { at } 4 \text { years } 10 \%\end{array}$ \\
\hline $\begin{array}{l}\text { Atik et al, } \\
2007[4]\end{array}$ & $\begin{array}{l}\text { Retrospective } \\
\text { case series }\end{array}$ & 30 & $\begin{array}{l}\text { Mean } \\
68 \pm 8\end{array}$ & $\begin{array}{l}\text { Left ventricle } \\
\text { Posterior, } 39 \\
\text { Lateral, } 29 \\
\text { Inferior, } 21 \\
\text { Anterior, } 11\end{array}$ & MI, 100 & Surgical, 30 & $\begin{array}{l}\text { Mean } 52 \pm \\
37 \text { months }\end{array}$ & $\begin{array}{l}\text { Surgical mortality } \\
20 \% \text { immediate and } \\
27 \%, 41 \% \text {, and } 55 \% \\
\text { at } 1,5 \text {, and } 8 \text { years }\end{array}$ \\
\hline
\end{tabular}

up. Thereafter, a cohort of conservatively managed patients from the Mayo Clinic experienced an overall 2-year survival rate of $63 \%$ [3]. Among the six medically treated patients who eventually died beyond this initial 2-year period, three died of non-cardiac causes, two of pre-existing congestive heart failure and one of acute MI. Importantly, no patient experienced further cardiac rupture. Most recently, Moreno et al reported an 1 - and 4-year survival rate of $88.9 \%$ among nine conservatively managed post-infarct pseudoaneurysm patients, and no progression to rupture in any case [11]. Interestingly, the cumulative incidence of ischemic stroke was high in these individuals ( $10 \%$ at 1 year and $33 \%$ at 4 years), although the issue of chronic anticoagulation in medically managed patients remains controversial. Of importance is the fact that compared to other series, the average size of pseudoaneurysm in this study was relatively small (mean posteroanterior diameter of 29.1 $\mathrm{mm}$, mean orifice diameter of $9.8 \mathrm{~mm}$ ). Furthermore, unlike in our case, median time to pseudoaneurysm diagnosis in these studies ranged from 3 to 9 months $[1,3,11]$.

Our patient's severe underlying pulmonary disease precluded aggressive surgical management. Although possible, it is unlikely that his pseudoaneurysm was chronic and diagnosed incidentally on a routine post-infarct echocardiogram, which was not obtained under a high pre-test suspicion for pseudoaneurysm. As such, his clinical profile - an asymptomatic, acute and moderately sized pseudoaneurysm - reflects a slightly different demographic than captured by the aforementioned series, and makes application of a robust evidence-based management decision challenging. Development of a centralized registry of cases may help to better elucidate the true natural history of this rare entity, and should be the focus of future studies especially as advances in non-invasive diagnostic modalities are made and diagnostic awareness increases.

\section{Grant Support}

None.

\section{References}

1. Frances C, Romero A, Grady D. Left ventricular pseudoaneurysm. J Am Coll Cardiol. 1998;32(3):557-561. 
2. Hulten EA, Blankstein R. Pseudoaneurysms of the heart. Circulation. 2012;125(15):1920-1925.

3. Yeo TC, Malouf JF, Oh JK, Seward JB. Clinical profile and outcome in 52 patients with cardiac pseudoaneurysm. Ann Intern Med. 1998;128(4):299-305.

4. Atik FA, Navia JL, Vega PR, Gonzalez-Stawinski GV, Alster JM, Gillinov AM, Svensson LG, et al. Surgical treatment of postinfarction left ventricular pseudoaneurysm. Ann Thorac Surg. 2007;83(2):526-531.

5. Pretre R, Linka A, Jenni R, Turina MI. Surgical treatment of acquired left ventricular pseudoaneurysms. Ann Thorac Surg. 2000;70(2):553-557.

6. Petrou E, Vartela V, Kostopoulou A, Georgiadou P, Mastorakou I, Kogerakis N, Sfyrakis P, et al. Left ventricular pseudoaneurysm formation: Two cases and review of the literature. World J Clin Cases. 2014;2(10):581-586.

7. Das AK, Wilson GM, Furnary AP. Coincidence of true and false left ventricular aneurysm. Ann Thorac Surg.
1997;64(3):831-834.

8. Zoffoli G, Mangino D, Venturini A, Terrini A, Asta A, Zanchettin C, Polesel E. Diagnosing left ventricular aneurysm from pseudo-aneurysm: a case report and a review in literature. J Cardiothorac Surg. 2009;4:11.

9. Alenghat FJ, Couper GS, Givertz MM. Giant left ventricular aneurysm as a late complication of inferior myocardial infarction. Eur Heart J. 2013;34(5):344.

10. Si D, Shi K, Gao D, Yang P. Ruptured left ventricular pseudoaneurysm in the mediastinum following acute myocardial infarction: a case report. Eur J Med Res. 2013;18:2.

11. Moreno R, Gordillo E, Zamorano J, Almeria C, GarciaRubira JC, Fernandez-Ortiz A, Macaya C. Long term outcome of patients with postinfarction left ventricular pseudoaneurysm. Heart. 2003;89(10):1144-1146.

12. Natarajan MK, Salerno TA, Burke B, Chiu B, Armstrong PW. Chronic false aneurysms of the left ventricle: management revisited. Can J Cardiol. 1994;10(9):927-931. 